\title{
ISRAEII LABOR MARKET AND THE FOURTH INDUSTRIAL REVOLUTION
}

\author{
Elisa Gotesman Bercovici ${ }^{1 *}$ and Adrian Bercovici ${ }^{2}$ \\ ${ }^{1) 2)}$ Bucharest University of Economic Studies, Bucharest, Romania
}

Please cite this article as:

Gotesman-Bercovici, E. and Bercovici, A., 2019.

Israeli Labor Market and the Fourth Industrial

Revolution. Amfiteatru Economic, 21(Special Issue

No. 13), pp. 884-895.

DOI: $10.24818 / \mathrm{EA} / 2019 / \mathrm{S} 13 / 884$

\section{Article History}

Received: 26 August 2019

Revised: 27 September 2019

Accepted: 7 October 2019

\begin{abstract}
In recent years, we have witnessed the effects of the Fourth Industrial Revolution on the labour market. Technological changes, internet use, and robotics are changing the practices, services, and needs of organizations and employees in the labour market. These changes represent both a threat and an opportunity for the significant economic development of many populations. This article aims to examine the current and expected implications of these changes in the labor market in Israel. The research presented in this article was conducted by in-depth interviews with two leading infrastructure organizations in Israel. These organizations have a broad understanding of the labour market gaps and opportunities, work with hundreds of actors in the labour market eco system (employment organizations, employees, employers, educational institutes, government, philanthropy). The results of the study suggest what some eco labour actors should do to cope with changes in the labour market due to the Fourth Industrial Revolution. We emphasis the need of new skills (up-skilling, re-skilling), Life Long Learning (LLL), new professional knowledge, and adopting further actions to older and diverse populations that will take a more significant part in the future labor market in Israel. In addition, we present some examples of programs that both researched organizations attempt to address these challenges in Israel.
\end{abstract}

Keywords: Industry 4.0, job mobility, employment discrimination, re-skilling, up-skilling, Life Long Learning, Non-Profit Organizations, employment organizations.

JEL Classification: A10, D7, D8, E24, J08.

* Corresponding author, Elisa Gotesman Bercovici - elisagotes@ gmail.com 


\section{Introduction}

In recent years we have witnessed the unfolding of the Fourth Industrial Revolution (or 4.0 Industrial revolution). Schwab (2016) states "this revolution is characterized by a fusion of technologies that is blurring the lines between the physical, digital, and biological spheres". Others describes "a world where individuals move between digital domains and offline reality with the use of technology to enable and manage their lives." (Xu, et al., 2018).

Arntz, et al. (2016) claim that the 4.0 Industrial revolution has been changing society as a whole and businesses in particular.

The technological advance brought by the 4.0 Industrial Revolution shifts the production and services of many industries towards digital characterization Sandru, et al., (2019). It includes artificial intelligence (AI), cloud technology, robotics, products designed by computers, three-dimensional printing (3D), automation, and industrial internet of things (IoT). Jolley (2018) states that the new Gig Economy (employees as independent contractors) will be more significant. This phenomenon will affect all types of sectors NPO's among them Gotesman Bercovici, et al. (2017).

Those changes will affect all labour market eco system (employment organizations, employees, employers, educational institutes, government, philanthropy). Most of today's skills required in different professions will soon become outdated. Jobs will disappear, and new ones will replace them. According to Mckinsey Global Institute, "by the year 2030 globally almost 375 million people have to learn and master fresh skills as their current jobs may evolve or perish along with the rise of automation and capable robots/machines." In the opinion of Annunziata, et al. (2018), the skills required by the new labor market will have to be "a combination of STEM (Science, Technology, Engineering and Math) and creativity, critical thinking and problem-solving abilities". The whole eco-system must support employee's reskilling (acquiring knowledge and new skills to have access to new jobs), and up-skilling (improving current knowledge and skills to enhance the quality of the job).

Skills can also be set by:

- Basic skills - digital orientation, basic mathematical ability

- Soft skills - interpersonal abilities, personal communication, proactive abilities

- Professional skills - familiarity with the new profession and its varying requirements

- Life Long Learning (LLL) - learn how to learn.

LLL is a diverse, flexible and available learning ability. It is no longer a learning that takes place formally, in a definite place and in a defined time, but rather a learning that is done by the learner, through different means, at different times and places. LLL does not just refer to the professional skills required for certain positions. It trains the employee for broader skills that can assist him in a variety of roles and in various areas of life. It also boosts a sense of independence, personal responsibility and proactivity. Moreover, it encourages creativity and initiative. In light of technological improvements, another phenomenon is expected to affect human life. Acording to United Nation Report (2015), estimates that in the decades to come, many more people will live towards the age of 100 . Therefore, the retirement age from work will change towards a later age than it is today (World Economic Forum, 2017). 
The changes mentioned above in the labor market can be an opportunity for adequate job mobility of general and discriminated employees both within existing organizations and in new ones. It is also an opportunity for self-employment. The eco-system must consider how employees will reach adequate job mobility by economic improvement, professional development, improved employment conditions, an enhanced sense of subjectivity regarding his employment status.

\section{Industry 4.0 and the Labor Market in Israel}

The Israeli labour market can be analyzed from several aspects. Some are evidence of its strength like the unemployment rate- 3.8\%, (Central Bureau of Statistics, Aug 2019), and its impressive High Tech sector. Other aspects indicate large gaps between populations that do or do not participate in the labor market.

Gini index in 2017 was $0.35 \%$ (after tax payments). Also, traditional Industries suffer from low productivity (OECD, 2017).

Diverse or discriminated populations that are growing at a fast pace are not sufficiently represented in the labour market today. Examples are the Arab population, Ultra-Orthodox men (Haredi), people with disabilities, Ethiopian Jews (Taub Centre Report, 2018). Moreover, some of those who are already employed find it difficult to advance to a better position. According to the Israeli Central Bureau of Statistics in 2018, by the year 2059, the proportion of this discriminated population will increase to $50 \%$ of the total population. The figure no. 1 shows the distribution of the labour force in Israel. "Non-Haredi" Jews refer to secular people (that are not included in the discriminated population).

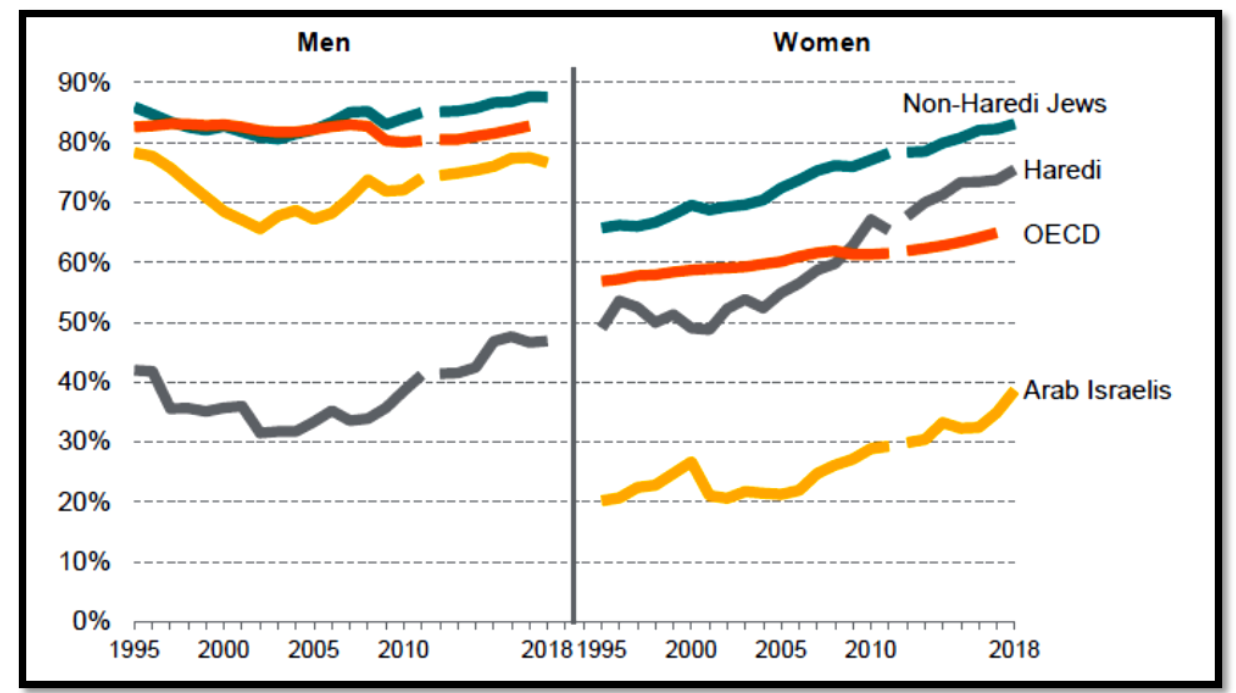

Figure no. 1: Employment rates by population group and gender Ages 25-64 in Israel

Source: Taub Center for Social Policy Studies in Israel, 2018, pp. 88. 
Observing at average life expectancy index, from World Health Organization 2018, Israel is ranked as the $9^{\text {th }}$ country in the world due to her the high average life expectancy -82.3 years (for both sexes).

Along with the expected changes in the labor market in light of the 4.0 Industrial revolution, actors in this eco-system should take more action in preparing themselves for the expected changes, especially regarding the discriminated population. (Gotesman Bercovici, et al., 2019)

\section{Research Methodology and Findings}

We collected information from 2 significant infrastructure organizations that develop new programs and have been advising, in the field of employment in Israel for the past two decades. Both organization work in collaboration with all the actors in the eco-system.

The organizations are: JDCTevet (Joint Distribution Committee) and Zionut2000.

We performed in-depth interviews with program managers of these organizations and analyzed data between the years 2017 and 2019.

We asked them:

- What implications does the 4.0 Industry revolution have on the employment market in Israel?

- What programs has your organization developed to address these challenges?

We asked the respondents to address several stages in the employment world (Table no. 1).

Table no. 1: Stages in the world of employment in Israel

\begin{tabular}{|c|l|l|l|l|}
\hline Stage & \multicolumn{1}{|c|}{ A } & \multicolumn{1}{c|}{ B } & \multicolumn{1}{c|}{ C } & \multicolumn{1}{c|}{ D } \\
\hline Content & $\begin{array}{l}\text { Preparation before } \\
\text { entering the labor } \\
\text { market. }\end{array}$ & $\begin{array}{l}\text { Recruitment } \\
\text { process }\end{array}$ & $\begin{array}{l}\text { Employées } \\
\text { promotion processes }\end{array}$ & $\begin{array}{l}\text { Preparation } \\
\text { for } \\
\text { retirement }\end{array}$ \\
\hline
\end{tabular}

We asked the respondents to address 3 points of view:

- Employee point of view (not self-employed)

- Employer organization point of view

- Employment organization point of view

In the next tables, we present the results, from each point of view concerning the current status and the future new demand in light of the 4.0 Industrial revolution.

Besides, we present examples of new programs that JDCTevet and Zionut2000 developed to deal with those new needs (Table no. 2). 
Table no. 2: Employee point of view

\begin{tabular}{|c|c|c|}
\hline Stage-Content & Current status & $\begin{array}{l}\text { Future demand in light of the } 4.0 \\
\text { Industrial revolution }\end{array}$ \\
\hline $\begin{array}{l}\text { A } \\
\text { Preparation } \\
\text { before entering } \\
\text { the labor } \\
\text { market }\end{array}$ & $\begin{array}{l}\text { New knowledge will be supplied } \\
\text { by other actors in the eco-system }\end{array}$ & $\begin{array}{l}\text { - Self LLL new skills, knowledge } \\
\text { - Self LLL about the eco-system of } \\
\text { his industry, employer corporate } \\
\text { culture ad the way they work } \\
\text { through on line information }\end{array}$ \\
\hline $\begin{array}{l}\text { Becruitment } \\
\text { process }\end{array}$ & $\begin{array}{l}\text { The employee is more guided by } \\
\text { the HR of the employer, or } \\
\text { employment organizations } \\
\text { through the recruitment process }\end{array}$ & $\begin{array}{l}\text { Employee will be more active and } \\
\text { controls or even influence his } \\
\text { recruitment process, using new } \\
\text { technological means }\end{array}$ \\
\hline $\begin{array}{l}\text { C } \\
\text { Employee's } \\
\text { promotion } \\
\text { processes }\end{array}$ & $\begin{array}{l}\text { The employee depends mainly on } \\
\text { the employer's willingness to } \\
\text { promote him. } \\
\text { - Promotion is interpreted as } \\
\text { advancement in the professional } \\
\text { responsibilities of the job } \\
\text { - Employees over the age of } 45 \\
\text { feel that the organization invests } \\
\text { less in their professional } \\
\text { development }\end{array}$ & $\begin{array}{l}\text { Employees take responsibility of } \\
\text { their promotion process through } \\
\text { LLL, develops new skills (up- } \\
\text { skilling; re-skilling) }\end{array}$ \\
\hline $\begin{array}{l}\text { D } \\
\text { Preparation } \\
\text { for retirement }\end{array}$ & $\begin{array}{l}\text { - The retirement age in Israel for } \\
\text { women is } 62 \text { and for men } 67 \\
\text { - Employees are not aware of all } \\
\text { their financial rights } \\
\text { - Employees fear from the } \\
\text { retirement } \\
\text { social aspect (loneliness) }\end{array}$ & $\begin{array}{l}\text { - The retirement age will advance } \\
\text { towards } 70-75 \text { (people will live } \\
\text { longer) } \\
\text { - Employees will be more active } \\
\text { and through LLL will manage their } \\
\text { rights and opportunities } \\
\text { - Employees will use new social } \\
\text { media } \\
\text { networks to discharge their fear of } \\
\text { loneliness after retirement }\end{array}$ \\
\hline $\begin{array}{l}\text { Examples of } \\
\text { programs that } \\
\text { meet the new } \\
\text { needs }\end{array}$ & \multicolumn{2}{|c|}{$\begin{array}{l}\text { Skill up (JDC Israel Tevet) } \\
\text { Aim of the program: to develop services that answer the needs of low- } \\
\text { paid and low-skilled workers over the age of } 25 \text {, by LLL mechanisms. } \\
\text { For small and medium employers up to } 500 \text { employees } \\
\text { Model of work: Professional short course for employees. } \\
\text { The employer will receive a voucher for each course and each employee } \\
\text { that he chooses. } \\
\text { In order to receive the voucher, the employer must commit to raising the } \\
\text { employee's salary at the end of training by at least } 6 \% \text {. }\end{array}$} \\
\hline $\begin{array}{l}\text { Examples of } \\
\text { programs that } \\
\text { meet the new } \\
\text { needs }\end{array}$ & \multicolumn{2}{|c|}{$\begin{array}{l}\text { WeCode (JDC Israel Tevet with high education, Ministry of Labour and } \\
\text { Social Welfare and Social Services) } \\
\text { Aim of the program: entering the high-tech world and development for } \\
\text { young people from the social and geographic periphery. } \\
\text { Admission to the program is based on unique qualifications, which know } \\
\text { the potential, motivation, perseverance and thinking patterns that are }\end{array}$} \\
\hline
\end{tabular}




\begin{tabular}{|l|l|l|}
\hline Stage-Content & Current status & $\begin{array}{l}\text { Future demand in light of the 4.0 } \\
\text { Industrial revolution }\end{array}$ \\
\hline \multirow{2}{*}{$\begin{array}{l}\text { Examples of } \\
\text { programs that } \\
\text { needs the new }\end{array}$} & $\begin{array}{l}\text { appropriate for the profession. Admission to the program is not based on } \\
\text { a previous academic degree, matriculation, psychometric or previous } \\
\text { programming experience. } \\
\text { Model of work: A combination of training and practical practice (about } \\
\text { a year) with mentors from the industry. }\end{array}$ \\
\hline $\begin{array}{l}\text { Skills Camp (JDC Israel Tevet) } \\
\text { Model of work: Ond improving them to remote, low-awareness populations. } \\
\text { responsibility in a group setting and in a new and non-routine } \\
\text { environment. In this situation, leaving the safe and familiar area, is } \\
\text { meant to simulate the changing world of work. In an unfamiliar } \\
\text { environment, the need for change and learning a variety of new skills are } \\
\text { key features. }\end{array}$ \\
\hline $\begin{array}{l}\text { Examples of } \\
\text { programs that } \\
\text { neet the new }\end{array}$ & $\begin{array}{l}\text { Talent Digital (JDC Israel Tevet with Google, Ministry of Social } \\
\text { Welfare and Social Services) } \\
\text { Aim of the program: it was developed due to the existing shortage of } \\
\text { manpower in the digital professions, together with the acknowledgement } \\
\text { of the fact that this industry does not have sufficient representation for } \\
\text { discriminated populations. } \\
\text { Assisting the government in creating a mechanism for identifying new } \\
\text { professions and building training in these areas. } \\
\text { Model of work: } \\
\text { Professional high-tech and digital short courses and training aimed at } \\
\text { discriminated populations. The program includes candidate recruitment, } \\
\text { screening, professional training along with soft skills and placement } \\
\text { assistance. }\end{array}$ \\
\hline
\end{tabular}

In the next table we present the employers' point of view. In this context, we present the conclusions about employers who are incorporated in business: companies Inc. that work with our research organizations, and not employers as government offices or NPO's organizations (Table no. 3).

Table no. 3: Employer organization point of view

\begin{tabular}{|l|l|l|}
\hline Stage-Content & Current status & $\begin{array}{l}\text { Future demand in light of the 4.0 } \\
\text { Industrial revolution }\end{array}$ \\
\hline $\begin{array}{l}\text { A } \\
\text { Preparation } \\
\text { the labor } \\
\text { market }\end{array}$ & $\begin{array}{l}\text { Employers relies mostly on the } \\
\text { employee or on others actors in } \\
\text { the eco-system to adjust to the } \\
\text { company needs for professional } \\
\text { training or skills (up-skilling; re- } \\
\text { skilling) before entering the labor } \\
\text { market }\end{array}$ & $\begin{array}{l}\text { Employers will more active in } \\
\text { developing new solutions together } \\
\text { with all the eco-system actors, in } \\
\text { order to welcome new candidates, } \\
\text { especially discriminated } \\
\text { populations }\end{array}$ \\
\hline $\begin{array}{l}\text { B } \\
\text { Recruitment } \\
\text { process }\end{array}$ & $\begin{array}{l}\text { The process is not satisfying } \\
\text { tailored to different employee's } \\
\text { needs, especially not for }\end{array}$ & $\begin{array}{l}\text { Employers will make more } \\
\text { necessary adjustments for divers' } \\
\text { population. }\end{array}$ \\
\hline
\end{tabular}




\begin{tabular}{|c|c|c|}
\hline Stage-Content & Current status & $\begin{array}{l}\text { Future demand in light of the } 4.0 \\
\text { Industrial revolution }\end{array}$ \\
\hline & $\begin{array}{l}\text { discriminated populations or old } \\
\text { age } \\
\text { - The recruitment process is not } \\
\text { enough transparent to the } \\
\text { candidate }\end{array}$ & $\begin{array}{l}\text { The process will be both internal } \\
\text { with HR and professional } \\
\text { managers, and external with other } \\
\text { eco system actors, that will make } \\
\text { use of new technological tools in } \\
\text { order to adjust more the recruitment } \\
\text { process to individual needs }\end{array}$ \\
\hline $\begin{array}{l}\text { C } \\
\text { Employées } \\
\text { promotion } \\
\text { processes }\end{array}$ & $\begin{array}{l}\text { Employers interprets employee } \\
\text { promotion mostly as vertical } \\
\text { promotion, climbing up to a } \\
\text { managerial position, or an } \\
\text { increase in salary and not by } \\
\text { investing in employee skills (up- } \\
\text { skilling; re-skilling) }\end{array}$ & $\begin{array}{l}\text { - Employers will have to allocate } \\
\text { organizational resources for the } \\
\text { development and implementation } \\
\text { of new skills and abilities for } \\
\text { employees } \\
\text { - Training courses will be offered } \\
\text { in a number of new ways, such as: } \\
\text { - delivered by the company (in } \\
\text { house); } \\
\text { - online courses; } \\
\text { - collaboration among companies } \\
\text { that might or might not work in the } \\
\text { same field of interest; } \\
\text { - make adjustments to the } \\
\text { organization culture and practices } \\
\text { for multi-age management of } \\
\text { employees } \\
\text { - promote more employees aged } \\
45+\end{array}$ \\
\hline $\begin{array}{l}\text { D } \\
\text { Preparation } \\
\text { for retirement }\end{array}$ & $\begin{array}{l}\text { Employers are relying mainly on } \\
\text { external organizations from the } \\
\text { eco system to prepare employees } \\
\text { for the retirement process }\end{array}$ & $\begin{array}{l}\text { - Employers will take more } \\
\text { significant part in preparing } \\
\text { employees for retirement by } \\
\text { providing relevant training on their } \\
\text { financial rights and social aspects } \\
\text { - make gradual necessary } \\
\text { organizational changes (practices, } \\
\text { knowledge, culture) to extend } \\
\text { employees retirement age towards } \\
70-75 \text { age }\end{array}$ \\
\hline $\begin{array}{l}\text { Examples of } \\
\text { programs that } \\
\text { meet the new } \\
\text { needs }\end{array}$ & \multicolumn{2}{|c|}{$\begin{array}{l}\text { Employment promotion (JDCIsrael Tevet with employers', } \\
\text { government) } \\
\text { Aim of the program: meant for low-wage workers from a variety of } \\
\text { discriminated populations that are not satisfied with their employment } \\
\text { status and who wish to advance in their current or other work. Define } \\
\text { their field of work according to their skills and occupational } \\
\text { predispositions. Improve their situation in one or more of the four } \\
\text { promotional dimensions: } \\
\text { - Economic improvement: increase in wages, expansion of office, }\end{array}$} \\
\hline
\end{tabular}




\begin{tabular}{|c|c|}
\hline Stage-Content & $\begin{array}{l}\text { Future demand in light of the } 4.0 \\
\text { Industrial revolution }\end{array}$ \\
\hline & $\begin{array}{l}\text { improvement of social conditions and related conditions. } \\
\text { - Professional Development: Promotion of the job by expanding } \\
\text { responsibilities, be more advanced or more professional. } \\
\text { - Improved working conditions: Beyond direct employment, more } \\
\text { flexible working hours, arrival time and the like. } \\
\text { - Subjective improvement: Improving employee satisfaction with work, } \\
\text { skills utilization, job security. } \\
\text { Model of work: Personal individual or group, long-term employment } \\
\text { guidance provided by professionals in the employment field. The } \\
\text { program is implemented together with employment organizations. }\end{array}$ \\
\hline $\begin{array}{l}\text { Examples of } \\
\text { programs that } \\
\text { meet the new } \\
\text { needs }\end{array}$ & 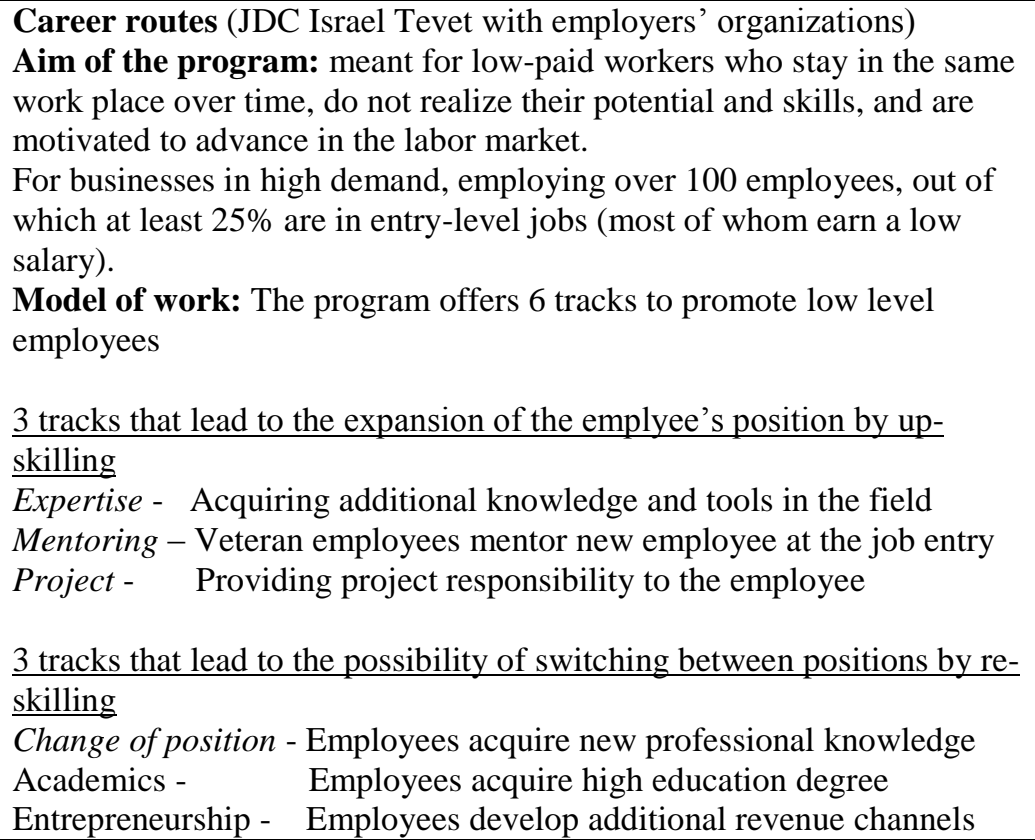 \\
\hline $\begin{array}{l}\text { Examples of } \\
\text { programs that } \\
\text { meet the new } \\
\text { needs }\end{array}$ & $\begin{array}{l}\text { Flywheel (Zionut } 2000 \text { with Beiahad Foundation) } \\
\text { Aim of the program: to create a network of businesses working } \\
\text { together as an answer of the growing demand for skilled workers in a } \\
\text { changing industrial landscape, low public investment in such programs, } \\
\text { low public perception, by improving training and education. } \\
\text { Model of work: Businesses working together (a group of } 30-40 \text { by } \\
\text { industry) on an ongoing and proactive basis, impacting the education, } \\
\text { training and employing new and existing employees within their sector, } \\
\text { in response to the expected changes. Goals to reach } 6 \text { sector-based } \\
\text { partnerships - each focused on } 1-2 \text { professions over a four-year period. } \\
\text { - The initiative started in } 2019 \text {, is in the early stages of building two } \\
\text { employer groups, in the construction and metal industries. }\end{array}$ \\
\hline
\end{tabular}




\begin{tabular}{|l|l|l|}
\hline Stage-Content & Current status & $\begin{array}{l}\text { Future demand in light of the 4.0 } \\
\text { Industrial revolution }\end{array}$ \\
\hline $\begin{array}{l}\text { Examples of } \\
\text { programs that } \\
\text { meet the new } \\
\text { need }\end{array}$ & $\begin{array}{l}\text { HUB 45-75 (Zionut2000 with JDC Israel Tevet, government) } \\
\text { Aim of the program: creating best practices models for business, to } \\
\text { work with older populations, aged between 45-75. } \\
\text { Model of work: Six large business organizations were selected to } \\
\text { develop models tailored to the needs of this population at all stages of } \\
\text { employment (A-D). } \\
\text { The models are developed together with all the actors in the eco-system } \\
\text { of the labour market. Results are expected by 2020 }\end{array}$ \\
\hline
\end{tabular}

In the next table we present employment organizations' point of view. There are dozens of those organizations, incorporated in three major forms:

- Opportunity centres: employment centers established by the Ministry of Social Welfare and Social Services. Those are urban and regional centers that coordinate all of the municipal programs available in the employment field for welfare populations.

- NPO's that specialize in weak or discriminated employees like: Be-atzmi (unemployed people for long time, without a high education background); Kavmashve (for Arab population); Olim Beyahad (for Etiopian academic population); Appleseeds Acadamy (Reducing digital gaps for all population).

- For profit employment organizations that start providing special programs to employers to work with discriminated population. An example of such an organization is Manpower Israel.

The majority of services which these organization offer, refer to the first stages in the world of employment in Israel A, B. Few programs relate to the stages C, D (Table no. 4).

Table no. 4: Employment organization point of view

\begin{tabular}{|c|c|c|}
\hline $\begin{array}{l}\text { Stage- } \\
\text { Content }\end{array}$ & Current status & $\begin{array}{l}\text { Future demand in light of the } 4.0 \\
\text { Industrial revolution }\end{array}$ \\
\hline $\begin{array}{l}\text { A } \\
\text { Preparation } \\
\text { before } \\
\text { entering the } \\
\text { labor } \\
\text { market }\end{array}$ & $\begin{array}{l}\text { Employment organization focus on } \\
\text { the technical side of the process for } \\
\text { finding a job (how to write a resume } \\
\text { correctly, how to look for positions). } \\
\text { It puts little emphasis on developing } \\
\text { skills of employees }\end{array}$ & $\begin{array}{l}\text { Employment organization will } \\
\text { provide more: } \\
\text { - training on improving skills } \\
\text { (basic, soft, LLL) } \\
\text { - professional training for new } \\
\text { professions }\end{array}$ \\
\hline $\begin{array}{l}\text { B } \\
\text { Recruitment } \\
\text { process }\end{array}$ & $\begin{array}{l}\text { Employment organisation } \\
\text { accompanies the candidate employee } \\
\text { for a short period of time through the } \\
\text { process of recruitment, without } \\
\text { paying enough attention to the needs } \\
\text { of the business organization }\end{array}$ & $\begin{array}{l}\text { - Employment organization will } \\
\text { guide and teach candidates how to } \\
\text { present their skills in the recruitment } \\
\text { process } \\
\text { - Employment organization will } \\
\text { guide the processes for a longer } \\
\text { period of time, along with paying } \\
\text { more attention to the future needs of } \\
\text { the employers }\end{array}$ \\
\hline $\mathrm{C}$ & Very few employment organizations & Employment organization will \\
\hline
\end{tabular}




\begin{tabular}{|c|c|c|}
\hline $\begin{array}{l}\text { Stage- } \\
\text { Content }\end{array}$ & Current status & $\begin{array}{l}\text { Future demand in light of the } \mathbf{4 . 0} \\
\text { Industrial revolution }\end{array}$ \\
\hline $\begin{array}{l}\text { Employées } \\
\text { promotion } \\
\text { processes }\end{array}$ & $\begin{array}{l}\text { are involved at this stage alongside } \\
\text { employers }\end{array}$ & $\begin{array}{l}\text { provide } \\
\text { new services to both employers and } \\
\text { employees, together with other eco } \\
\text { system actors like: } \\
\text { - training process of employees } \\
\text { require } \\
\text { new skills (up-skilling; LLL) } \\
\text { - in the process of learning new } \\
\text { professions (re-skilling) } \\
\text { - in the process of further job } \\
\text { mobility for new divers' employees }\end{array}$ \\
\hline $\begin{array}{l}\text { D } \\
\text { Preparation } \\
\text { for } \\
\text { retirement }\end{array}$ & $\begin{array}{l}\text { There are currently only } 6 \\
\text { employment organizations (all } \\
\text { NPO's) that specialize in employees } \\
\text { aged } 45-75 \text {. } \\
\text { Mostly supportive of unemployed } \\
\text { workers, finding second / third } \\
\text { careers }\end{array}$ & $\begin{array}{l}\text { - There will be dozens of } \\
\text { employments } \\
\text { organizations specialized in workers } \\
\text { aged } 45-75 \\
\text { - Employment organization will } \\
\text { play a major role in the process of } \\
\text { delaying the retirement age to } 75 \text {, by } \\
\text { offering their help in training the eco } \\
\text { system actors in multi-age } \\
\text { management new needs }\end{array}$ \\
\hline $\begin{array}{l}\text { Examples of } \\
\text { programs } \\
\text { that meet the } \\
\text { new needs }\end{array}$ & \multicolumn{2}{|c|}{$\begin{array}{l}\text { Emtza Haderch (JDC Israel Tevet with Ashalim, government) } \\
\text { Aim of the program: to provide employment guidance centers for the } \\
\text { population aged 45-75, based on existing urban employment or a different } \\
\text { infrastructure. } \\
\text { The development of employer relationships in the program will be carried } \\
\text { out with the aim of increasing the integration of the older population into } \\
\text { quality employment, understanding the barriers of employers in hiring the } \\
\text { older population, and building intervention programs that will reduce or } \\
\text { resolve these barriers. } \\
\text { Model of work: implemented in } 3 \text { cities in different ways: } \\
\text { Short-term intervention - completion, updates, soft skills development and } \\
\text { placement } \\
\text { Long / Modular Track - professional training / retraining, updating and } \\
\text { placement } \\
\text { Business Entrepreneurship Development - develop self employment } \\
\text { capabilities }\end{array}$} \\
\hline
\end{tabular}

As part of the response for the trend towards more independent workers, JDC Israel Tevet (in collaboration with other actors in the eco system) have developed several programs. One of them is Link: Online Trade Skills Program.

Aim of the program: to give discriminated employees, that are out of the labor market, an opportunity to return to the developing labor market in the field of online commerce (E-commerce) 
Model of work: offers a broad and ongoing holistic response to the needs of an online actor, throughout the first year of operation, from training to business operations.

The program operates in three ways that match the 4.0 Industrial revolution needs:

E-skills: developing personal skills with an emphasis on proactivity and motivation, selfmanagement skills, communication, collaboration and teamwork, networking and personal branding.

E-commerce: professional knowledge.

E-community: developing awareness of the possibilities and benefits of business relationships and community.

Moreover, the interviews with the two infrastructure organizations, JDCTevet and Zionut2000, point to the need of all the actors in the ecosystem to collaborate in view of adjusting to such a significant change in the labor market.

\section{Conclusion}

The last few years have been characterized by the 4.0 Industrial Revolution, where the labor market deals with significant transformations that result from changes in technologies, developments in the fields AI, cloud technology, robotics, (3D), automation and IoT. This change can bring about challenges, on the one hand, and many opportunities for the actors of the ecosystem labour market, on the other. Many professions may disappear, while others will be renewed or brand new.

Alongside with new professions and knowledge, employees will be required to have new, improved skills and professions. Adding to these challenges, in Israel, we witness two more aspects that are worth paying attention to. First, the retirement age is being delayed. Second, by the year 2059, the proportion of the discriminated employee population will increase to $50 \%$ of the total population. The research shows that all the actors in the ecosystem labour market should be responsible for coping with these changes and looking for feasible solutions. We stressed the changes to be made by three actors from the ecosystem labour market: the employee, the employer, and the employment organization. The critical changes that employees will need to adopt will be to "learn how to learn" by themselves, to acquire new skills and to be proactive given their job mobility.

Employers play an important role in employees' new training skills and professional promotion. This can be done by allocating resources, changing practices, creating an environment of training new or existing employees (as part as up-skilling or re-skilling). All of the above can make employees more efficient and effective in the long run. Besides, organizations will have to adjust themselves to working with older employees, and so will have to demonstrate multi age management. Employment organizations will provide new services to the actors in the ecosystem labor market. They will have to understand the needs of employers better, to be more involved in each stage of the employment world in Israel (A to D).

One of the limitations of this research is the relatively small number of participants. Therefore, we recommend further research into the part each actor in the eco system labour market should play. 


\section{Bibliography}

Annunziata, M. and Bourgeois, H., 2018. The future of work: how G20 countries can leverage digital-industrial innovations into stronger high- quality jobs growth. Economics, 12(42), pp.1-23.

Arntz, M.T., Gregory, T. and Zierahn, U., 2016. The risk of automation for jobs in OECD countries: A comparative analysis. [pdf] OECD Social, Employment and Migration Working Papers, No. 189. Available at: <https://www.oecd-ilibrary.org/docserver/ 5jlz9h56dvq7-en.pdf?expires $=1570560907 \&$ id $=$ id \&accname $=$ guest $\&$ checksum $=$ 32C339431A6F50D0476A43C3260A3E29> [Accessed 12 May 2018].

Gotesman Bercovici., E, Bercovici, A., 2019. Effects of the fourth industrial revolution on Israeli labour market. In: New Trends in Sustainable Business and Consumption, (BASIQ 2019), Bari, Italy, 30 May - 1 June 2019.

Gotesman Bercovici., E, Mateiu., A and Bercovici., A, 2017. Evaluation of outsourcing performances: a study of outsourcing in the area/field of NGOs. In: New Trends in Sustainable Business and Consumption (BASIQ 2017). Graz, Austria, 31 May-3 June 2017.

Jolley, D., 2018. Myths of the Gig Economy, Corrected. Harvard Business Review. [online] Available at: <https://hbr.org/2018/10/myths-of-the-gig-economy-corrected> [Accessed 8 September 2019].

McKinsey Global Institute 2017. Jobs lost, jobs gained: what the future of work will mean for jobs, skills, and wages. Report, December 2017. [online] Available at: <www.mckinsey.com/featured-insights/future-of-work/jobs-lost-jobs-gained-what-thefuture-of-work-will-mean-for-jobs-skills-and-wages> [Accessed 8 September 2019].

Sandru, M., Olaru, M. and Gotesman Bercovici, E., 2019. A study on the earned value as support for business processes improvement in the context of industry 4.0. International Journal of Advanced Engineering and Management Research, 4(2), pp.1-12.

Schwab, K., 2016. The Fourth Industrial Revolution. New York: Crown Business.

Taub Center, 2018. State of the National Report, [online] Available at: <www.taubcenter.org.il/> [Accessed 8 September 2019].

UN, 2015. World Population Project to Reach 9.7 Billions by 2050, [online] Available at: <www.un.org/en/development/desa/news/population/2015-report.html> [Accessed 8 September 2019].

World Economic Forum, 2016. The Future of Jobs Report, [online] Available at: <http://www3.weforum.org/docs/WEF_Future_of_Jobs.pdf> [Accessed 8 September 2019].

World Economic Forum, 2017. Realizing Human Potential in the Fourth Industrial Revolution Report. [online] Available at: <http://www3.weforum.org/ docs/WEF_EGW_Whitepaper.pdf> [Accessed 20 September 2019].

World Economic Forum, 2018. The Future of Jobs Report, [online] Available at: <https://www.weforum.org/reports/the-future-of-jobs-report-2018> [Accessed 8 September 2019].

World Health Organization, 2018. Global Health Observatory Report, [online] Available at: <https://www.who.int/gho/publications/world_health_statistics/2017/dashboard/en/> [Accessed 20 September 2019].

Xu, M., David, J.M. and Kim, S.H., 2018. The Fourth Industrial Revolution: Opportunities and Challenges. International Journal of Financial Research, 9(2), pp.90-95. 